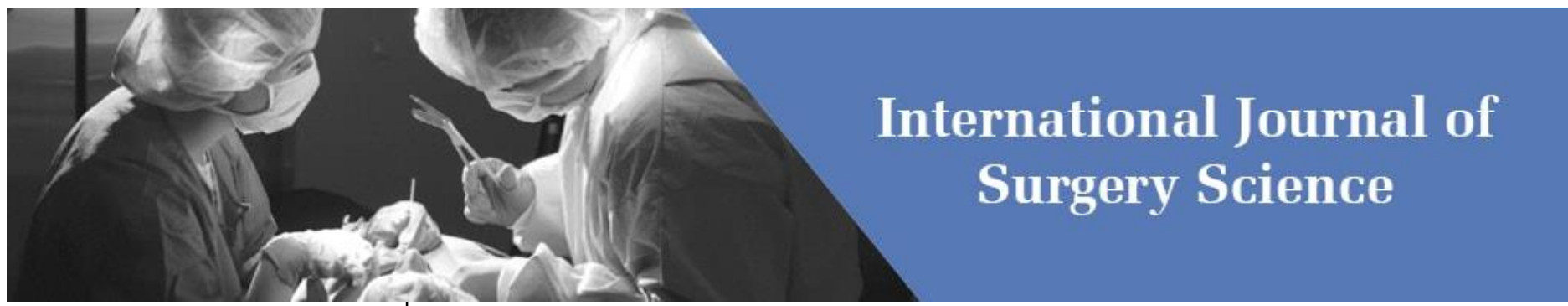

E-ISSN: 2616-3470

P-ISSN: 2616-3462

(C) Surgery Science

www.surgeryscience.com

2020; 4(2): 158-163

Received: 14-02-2020

Accepted: 15-03-2020

\section{Abdullah Shuaib}

Department of General Surgery,

Jahra Hospital, Jahra, Kuwait

Mubarak Alasaousi

Resident in Kuwaiti Board of

General Surgery, Kuwait Institute

of Medical Specializations, Kuwait

Ahmed M Gawali

Department of General Surgery, Jahra Hospital, Jahra, Kuwait

Mohamed Alaa Sallam

Department of General Surgery, Jahra Hospital, Jahra, Kuwait
Corresponding Author:

Abdullah Shuaib

Department of General Surgery,

Jahra Hospital, Jahra, Kuwait

\section{Traumatic appendicitis: Is it a fairy tale? A literature review}

\section{Abdullah Shuaib, Mubarak Alasaousi, Ahmed M Gawali and Mohamed Alaa Sallam}

DOI: https://doi.org/10.33545/surgery.2020.v4.i2c.411

\section{Abstract}

Acute appendicitis is the most common surgical condition in patients presenting to emergency departments worldwide. It was only in the early 1930s that the relationship between blunt trauma and acute appendicitis was reported. Searches on the terms "traumatic appendicitis" and "appendicitis post blunt trauma" in PubMed, Google, and Medline yielded 23 full-text articles about traumatic appendicitis. The articles reported on acute post-traumatic appendicitis. Nevertheless, the relationship between acute appendicitis and trauma is still controversial. A few theories have attempted to explain the relationship; however, a definitive cause has not yet been identified. A patient presenting with right iliac fossa or diffuse abdominal pain after a traumatic event should be investigated, and acute appendicitis should be included in a differential diagnosis.

Keywords: Appendicitis, fairy tale, worldwide

\section{Introduction}

Acute appendicitis is the most common surgical condition in patients presenting to emergency departments worldwide. The mechanisms behind acute appendicitis have been explained by obstructions of the appendix lumen by fecaliths or foreign bodies ${ }^{[1,2]}$. It was only in the early 1930s that the relationship between blunt trauma and acute appendicitis was reported ${ }^{[3,4,1]}$. The most famous figure who was speculated to have died from acute appendicitis after multiple blows to the abdomen was the magician Houdini in $1926^{[2]}$. Whether acute appendicitis in a trauma setting is an incidental or casual finding is unclear. The aim of this literature review was to seek evidence about the possibility of the implementation of a traumatic appendicitis diagnosis.

\section{Methods}

Searches on the terms "traumatic appendicitis," "appendicitis post trauma," and "appendix injury" were performed in PubMed, Google, and Medline between August and October 2019. The inclusion criterion was full-text English-language articles. The exclusion criteria were articles with only abstracts or summaries. Twenty-three full-text published articles on traumatic or post-traumatic appendicitis were found.

\section{Results}

The total number of patients reported in the articles was 39: 36 males and 3 females ${ }^{[5,6]}$. Each had been healthy prior to experiencing a traumatic event in the preceding 1-48 hours. Three cases were described as appendix injury or post-traumatic perforation ${ }^{[7-9]}$. One case was caused by a penetrating stab wound in the right lower abdomen ${ }^{[10]}$. The search results are summarized in Table 1. All the patients had been exposed to abdominal trauma, such as seat belt injuries, blows to the abdomen, assaults, and bicycle injuries. The age range was 5-65 years. The applied diagnostic modules were ultrasonography and computed tomography of the abdomen (Table 2). Some articles provided no documentation on the diagnostic modulates ${ }^{[1,3,5,7]}$. One article did not specify the diagnostic investigations that were performed ${ }^{[5]}$.

Fowler published a report on 48 cases that had been diagnosed as acute appendicitis caused by external trauma in industrial accidents; however, details were not provided ${ }^{[3]}$. He emphasized the lack of proper documentation of traumatic events and their times of occurrence. 
This was attributed to the patients' manipulation of the period between trauma and injury to benefit from the compensation laws ${ }^{[3]}$. For linkage, most experts at that historical period set an interval of 48 hours between the clinical symptoms and the traumatic event ${ }^{[3]}$. A period of more than 48 hours between symptoms and a traumatic event would rule out a relationship ${ }^{[3]}$. Fowler stated that some cases were diagnosed intraoperatively as acute appendicitis; however, the results of histological examinations indicated otherwise ${ }^{[3]}$.

Table 1: Searched articles with number of cases

\begin{tabular}{|c|c|c|}
\hline Author & Publication year & Number of cases \\
\hline Thomas $^{[7]}$ & 1978 & 1 \\
\hline Hennington $^{[1]}$ & 1990 & 2 \\
\hline Ciftci $^{[6]}$ & 1996 & 5 \\
\hline Hagger $^{[11]}$ & 2002 & 1 \\
\hline Ramesh $^{[12]}$ & 2002 & 1 \\
\hline Karavokyros $^{[13]}$ & 2004 & 5 \\
\hline Etensel $^{[14]}$ & 2005 & 1 \\
\hline Toumi $^{[15]}$ & 2010 & 1 \\
\hline Torres-Grau $^{[16]}$ & 2012 & 8 \\
\hline Wani $^{[5]}$ & 2013 & 1 \\
\hline Bouassria $^{[10]}$ & 2013 & 1 \\
\hline Moslemi $^{[8]}$ & 2013 & 2 \\
\hline Ahmed $^{[17]}$ & 2014 & 1 \\
\hline Gupta $^{[18]}$ & 2016 & 1 \\
\hline Seung $^{[9]}$ & 2016 & 1 \\
\hline Jensen $^{[19]}$ & 2016 & 1 \\
\hline Khilji $^{[2]}$ & 2017 & 1 \\
\hline Siddiqui $^{[4]}$ & 2018 & 1 \\
\hline Singh $^{[20]}$ & 2018 & 1 \\
\hline AlJaberi $^{[21]}$ & 2018 & 1 \\
\hline Çağlar $^{[22]}$ & 2018 & 39 \\
\hline O'Kelly $^{[23]}$ & 2019 & \\
\hline & & \\
\hline & & \\
\hline & & \\
\hline
\end{tabular}

Table 2: Diagnostic investigations

\begin{tabular}{|c|c|c|}
\hline Author & CT scan abdomen & Ultrasonography of the abdomen \\
\hline Thomas ${ }^{[5]}$ & Not done & Not done \\
\hline Hennington ${ }^{[1]}$ & Not done & Not done \\
\hline Hennington ${ }^{[1]}$ & Not done & Not done \\
\hline Ciftci ${ }^{[6]}$ & Not done & Not done \\
\hline Ciftci ${ }^{[6]}$ & Not done & Not done \\
\hline Ciftci ${ }^{[6]}$ & Not done & Not done \\
\hline Ciftci ${ }^{[6]}$ & Not done & Dilated bowel loops \\
\hline Ciftci $^{[6]}$ & Not done & Dilated bowl loops \\
\hline Hagger ${ }^{[11]}$ & $\begin{array}{l}\text { Dilated loops of small bowel, incarceration of edematous bowel in a right } \\
\text { inguinal hernia, and edematous changes in the right perirenal tissues }\end{array}$ & Not done \\
\hline Ramesh ${ }^{[12]}$ & Not done & Bilateral iliac fossa fluid collection. \\
\hline Karavokyros ${ }^{[13]}$ & Not done & $\begin{array}{l}\text { Free peritoneal fluid mainly around the } \\
\text { liver }\end{array}$ \\
\hline Etensel $^{[14]}$ & Not done & Large abdo fluid, hepatic lacerations \\
\hline Etensel ${ }^{[14]}$ & Not done & $\begin{array}{l}\text { Large hepatic laceration, free fluid and } \\
\text { retroperitoneal hematoma }\end{array}$ \\
\hline Etensel $^{[14]}$ & Not done & Retroperitoneal hematoma \\
\hline Etensel $^{[14]}$ & Free air & Free air \\
\hline Etensel $^{[14]}$ & $\begin{array}{l}\text { Splenic laceration, free fluid (large volume), pneumomediastinum, left } \\
\text { hemidiaphragm and left ureteropelvic junction and urinoma }\end{array}$ & Not done \\
\hline Toumi ${ }^{[15]}$ & Appendicitis with an adjacent collection & Not done \\
\hline Torres-Grau ${ }^{[16]}$ & Not done & $\begin{array}{l}\text { Normal liver, gallbladder, spleen and } \\
\text { kidneys, with no evidence of presence of } \\
\text { free fluids }\end{array}$ \\
\hline Wani ${ }^{[5]}$ & Used but no specifications & Used but no specifications \\
\hline Wani ${ }^{[5]}$ & Used but no specifications & Used but no specifications \\
\hline Wani ${ }^{[5]}$ & Used but no specifications & Used but no specifications \\
\hline Wani ${ }^{[5]}$ & Used but no specifications & Used but no specifications \\
\hline Wani [5] & Used but no specifications & Used but no specifications \\
\hline Wani ${ }^{[5]}$ & Used but no specifications & Used but no specifications \\
\hline Wani [5] & Used but no specifications & Used but no specifications \\
\hline Wani $\left[{ }^{5]}\right.$ & Used but no specifications & Used but no specifications \\
\hline
\end{tabular}




\begin{tabular}{|c|c|c|}
\hline Bouassria $^{[10]}$ & Not done & Normal \\
\hline Moslemi ${ }^{[8]}$ & $\begin{array}{l}\text { Two small foci of air in the anterior aspect of the abdomen, in favor of } \\
\text { pneumoperitoneum }\end{array}$ & $\begin{array}{l}\text { Mild to moderate free fluid in the } \\
\text { abdominopelvic cavity }\end{array}$ \\
\hline Ahmed ${ }^{[17]}$ & Not done & $\begin{array}{l}\text { Fluid in the pelvis suggestive of } \\
\text { hemoperitoneum }\end{array}$ \\
\hline Gupta $[18]$ & Not done & $\begin{array}{l}\text { An appendicular lump with free fluid in } \\
\text { the pelvis, without solid organ injury }\end{array}$ \\
\hline Gupta ${ }^{[18]}$ & $\begin{array}{l}\text { Mild to moderate free fluid in the pelvis. No signs of pneumoperitoneum } \\
\text { or solid organ injury. }\end{array}$ & Not mentioned \\
\hline Seung ${ }^{[9]}$ & $\begin{array}{l}\text { Small amount of fluid collection in the pelvic cavity without } \\
\text { pneumoperitoneum or extravasation of contrast }\end{array}$ & $\begin{array}{l}\text { Small amount of fluid collection in the } \\
\text { pelvic cavity }\end{array}$ \\
\hline Jensen ${ }^{[19]}$ & $\begin{array}{l}\text { Demonstrated moderate stranding in the anterior abdomen and lower } \\
\text { right quadrant. }\end{array}$ & Not done \\
\hline Khilji [2] & $8 \mathrm{~mm}$ thickening of appendix with minimal adjacent fat stranding & No free fluid in the abdominal cavity \\
\hline Siddiqui ${ }^{[4]}$ & $\begin{array}{c}\text { Displayed an inflamed and distended distal appendix, the tip of which } \\
\text { was located in the right upper quadrant }\end{array}$ & Not done \\
\hline Singh ${ }^{[19]}$ & Not done & $\begin{array}{l}\text { Normal organ systems with minimal to } \\
\text { mild ascites and low-level echoes }\end{array}$ \\
\hline AlJaberi ${ }^{[20]}$ & Minimal free fluid and a degree of inflammation of the appendix & Not done \\
\hline Çağlar ${ }^{[21]}$ & $\begin{array}{l}\text { No vital organ injury, but inflamed acute appendix and minimal pelvic } \\
\text { free fluid }\end{array}$ & Not done \\
\hline O’Kelly ${ }^{[22]}$ & $\begin{array}{l}\begin{array}{l}\text { Evidence of an inflammatory lesion in the right iliac fossa with evidence } \\
\text { of hemoperitoneum }\end{array} \\
\end{array}$ & Not done \\
\hline
\end{tabular}

Table 3: Initial symptoms and time interval between trauma and symptoms

\begin{tabular}{|c|c|c|}
\hline Author & Time interval between trauma and symptoms & Initial symptoms \\
\hline Thomas ${ }^{[7]}$ & $4-6$ hours & Tenderness in lower abdomen \\
\hline Hennington ${ }^{[1]}$ & $\begin{array}{l}1^{\text {st }} \text { case: } 48 \text { hours } \\
2^{\text {nd }} \text { case: } 12 \text { hours }\end{array}$ & Severe pain in lower abdomen \\
\hline Ciftci ${ }^{[6]}$ & Not mentioned & Not mentioned \\
\hline Hagger $^{[11]}$ & 72 hours & Right lower quadrant pain; worse on movement \\
\hline Ramesh $^{[12]}$ & 48 hours & Persistent abdominal pain, nausea and vomiting \\
\hline Karavokyros $[13]$ & 12 hours presumably & $\begin{array}{c}\text { Vague abdominal pain and dysuria without concomitant } \\
\text { diarrhea or vomiting }\end{array}$ \\
\hline Etensel $^{[14]}$ & $\begin{array}{l}1^{\text {st }} \text { case: } 4 \text { hours } \\
2^{\text {nd }} \text { case: } 1 \text { hour } \\
3^{\text {rd }} \text { case: } 1 \text { hour } \\
4^{\text {th }} \text { case: } 1 \text { hour } \\
5^{\text {th }} \text { case: } 15 \text { mins }\end{array}$ & All with lower abdomen pain with or without abrasions \\
\hline Toumi ${ }^{[15]}$ & Immediately & Sever lower abdomen pain \\
\hline Torres-Grau $^{[16]}$ & 6 hours & Sever right sided abdominal pain \\
\hline Wani ${ }^{[5]}$ & 24 hours -4 days & Lower abdomen pain \\
\hline Bouassria ${ }^{[10]}$ & 24 hours & Right iliac fossa pain post stab \\
\hline Moslemi ${ }^{[8]}$ & 6 hours & Diffuse abdominal pain with fever \\
\hline Ahmed $^{[17]}$ & 48 hours & Right lower abdominal pain \\
\hline Gupta $^{[18]}$ & $\begin{array}{l}1^{\text {st }} \text { case: } 96 \text { hours } \\
2^{\text {nd }} \text { case: } 72 \text { hours }\end{array}$ & Severe abdominal pain in both cases \\
\hline Seung $[9]$ & 8 hours & $\begin{array}{l}\text { Pain in the periumbilical area as well as the lower } \\
\text { abdomen }\end{array}$ \\
\hline Jensen $^{[19]}$ & 6 hours & Acute abdominal pain and nausea \\
\hline Khilji ${ }^{[2]}$ & 2 hours & Abdominal pain \\
\hline Siddiqui ${ }^{[4]}$ & 1 hour & Right shoulder and lateral right hip \\
\hline Singh ${ }^{[20]}$ & 48 hours & Abdominal pain \\
\hline AlJaberi ${ }^{[21]}$ & 30 minutes & Right flank pain \\
\hline Çağlar ${ }^{[22]}$ & 24 hours & Abdominal pain \\
\hline $\mathrm{O}^{\prime}$ Kelly ${ }^{[23]}$ & 24 hours & Sudden progressive right lower quadrant pain \\
\hline
\end{tabular}

Table 4: Trauma mechanisms, surgical intervention, intraoperative findings, and histology

\begin{tabular}{|c|c|c|c|c|}
\hline Author & Mechanism of trauma & Procedure & Intra-operative findings & Histology \\
\hline Thomas $^{[5]}$ & $\begin{array}{c}\text { Low-velocity crush injury; } \\
\text { patient was trapped between } \\
\text { stationary and slow-moving } \\
\text { vehicles }\end{array}$ & $\begin{array}{c}\text { Open appendectomy } \\
\text { via right } \\
\text { paramedian incision }\end{array}$ & $\begin{array}{c}\text { Torn mesoappendix: the } \\
\text { appendix itself was } \\
\text { completely severed at the } \\
\text { junction of its proximal } \\
\text { third and distal two-thirds }\end{array}$ & $\begin{array}{c}\text { The appendix showed a small } \\
\text { fecalith in the severed portion } \\
\text { and mild but definite } \\
\text { inflammatory changes confined } \\
\text { to the mucosa of both portions. }\end{array}$ \\
\hline Hennington $^{[1]}$ & $\begin{array}{c}\text { Engine transmission }(200 \mathrm{lb}) \\
\text { fell on patient's abdomen }\end{array}$ & Open appendectomy & Gangrenous appendix & Not mentioned \\
\hline Hennington ${ }^{[1]}$ & $\begin{array}{c}\text { Bicycle handlebar injury to his } \\
\text { lower abdomen. }\end{array}$ & Open appendectomy & $\begin{array}{c}\text { Acute suppurative } \\
\text { appendicitis }\end{array}$ & Not mentioned \\
\hline
\end{tabular}




\begin{tabular}{|c|c|c|c|c|}
\hline Ciftci $^{[6]}$ & RTA (pedestrian) & Open appendectomy & Perforated appendix & Appendicitis \\
\hline Ciftci ${ }^{[6]}$ & Fall & Open appendectomy & Acute appendicitis & Appendicitis \\
\hline Ciftci $^{[6]}$ & Accident (ball) & Open appendectomy & Acute appendicitis & Appendicitis \\
\hline Ciftci $^{[6]}$ & RTA & Open appendectomy & Perforated appendix & Appendicitis \\
\hline Ciftci ${ }^{[6]}$ & Assault & Open appendectomy & Acute appendicitis & Appendicitis \\
\hline Hagger ${ }^{[11]}$ & $\begin{array}{c}\text { Patient fell from approximately } \\
6 \text { feet and landed prone on the } \\
\text { rungs of the ladder }\end{array}$ & Open appendectomy & $\begin{array}{l}\text { Gangrenous appendix with } \\
\text { free pus }\end{array}$ & Not mentioned \\
\hline Ramesh ${ }^{[12]}$ & $\begin{array}{l}\text { Bicycle handlebar injury to } \\
\text { patient's lower abdomen. }\end{array}$ & $\begin{array}{l}\text { Laparotomy with } \\
\text { appendectomy }\end{array}$ & $\begin{array}{l}\text { Pus in the abdomen and a } \\
\text { perforated appendix }\end{array}$ & Not mentioned \\
\hline Karavokyros ${ }^{[13]}$ & $\begin{array}{l}\text { Assault (blunt abdominal } \\
\text { trauma) }\end{array}$ & $\begin{array}{l}\text { Laparotomy with } \\
\text { appendectomy }\end{array}$ & $\begin{array}{l}\text { Inflamed appendix, a few } \\
\text { enlarged mesenteric lymph } \\
\text { nodes and free peritoneal } \\
\text { fluid }\end{array}$ & Confirmed appendicitis \\
\hline Etensel ${ }^{[14]}$ & RTA & $\begin{array}{l}\text { Laparotomy + } \\
\text { appendectomy }\end{array}$ & $\begin{array}{c}\text { Hepatic lacerations + } \\
\text { appendicitis } \\
\end{array}$ & Confirmed appendicitis \\
\hline Etensel ${ }^{[14]}$ & RTA & $\begin{array}{l}\text { Laparotomy + } \\
\text { appendectomy }\end{array}$ & $\begin{array}{l}\text { Hyperemic, edematous, } \\
\text { thickened appendix }\end{array}$ & Confirmed appendicitis \\
\hline Etensel $^{[14]}$ & RTA & $\begin{array}{l}\text { Laparotomy }+ \\
\text { appendectomy }\end{array}$ & $\begin{array}{l}\text { Hyperemic, inflamed } \\
\text { appendix }\end{array}$ & Confirmed appendicitis \\
\hline Etensel $^{[14]}$ & Fall & $\begin{array}{l}\text { Laparotomy }+ \\
\text { appendectomy }\end{array}$ & $\begin{array}{l}\text { Hyperemic, edematous, } \\
\text { thickened appendix }\end{array}$ & Confirmed appendicitis \\
\hline Etensel ${ }^{[14]}$ & RTA (pedestrian) & $\begin{array}{l}\text { Laparotomy + } \\
\text { appendectomy }\end{array}$ & $\begin{array}{l}\text { Hyperemic, edematous, } \\
\text { thickened appendix }\end{array}$ & Confirmed appendicitis \\
\hline Toumi ${ }^{[15]}$ & Fall and blow to abdomen & Open appendectomy & $\begin{array}{l}\text { retrocecal appendix was } \\
\text { grossly inflamed and } \\
\text { necrotic }\end{array}$ & $\begin{array}{l}\text { Acute suppurative appendicitis } \\
\text { with serositis }\end{array}$ \\
\hline Torres-Grau ${ }^{[16]}$ & Fall from 2 meters & $\begin{array}{l}\text { Laparoscopy + } \\
\text { appendectomy }\end{array}$ & $\begin{array}{l}\text { Necrotic, non-perforated } \\
\text { appendix }\end{array}$ & Confirmed appendicitis \\
\hline Wani ${ }^{[5]}$ & Fall & Open appendectomy & Features of appendicitis & Confirmed appendicitis \\
\hline Wani [5] & Fall & Open appendectomy & Features of appendicitis & Confirmed appendicitis \\
\hline Wani ${ }^{[5]}$ & Fall & Open appendectomy & Features of appendicitis & Confirmed appendicitis \\
\hline Wani $^{[5]}$ & Kicked in the abdomen & Open appendectomy & Features of appendicitis & Confirmed appendicitis \\
\hline Wani ${ }^{[5]}$ & Kicked in the abdomen & Open appendectomy & Features of appendicitis & Confirmed appendicitis \\
\hline Wani ${ }^{[5]}$ & Kicked in the abdomen & Open appendectomy & Features of appendicitis & Confirmed appendicitis \\
\hline Wani ${ }^{[5]}$ & Kicked in the abdomen & Open appendectomy & Features of appendicitis & Confirmed appendicitis \\
\hline Wani ${ }^{[5]}$ & $\begin{array}{l}\text { Compression on the right lower } \\
\text { abdomen by a bicycle handlebar }\end{array}$ & Open appendectomy & Features of appendicitis & Confirmed appendicitis \\
\hline Bouassria ${ }^{[10]}$ & $\begin{array}{l}\text { Penetrating stab wound to the } \\
\text { abdomen }\end{array}$ & $\begin{array}{l}\text { Laparotomy + } \\
\text { appendectomy }\end{array}$ & $\begin{array}{c}\text { Appendix was hyperemic } \\
\text { and edematous }\end{array}$ & $\begin{array}{c}\text { Confirmed diagnosis of acute } \\
\text { appendicitis }\end{array}$ \\
\hline Moslemi ${ }^{[8]}$ & $\begin{array}{l}\text { Bicycle handlebar injury to the } \\
\text { lower abdomen }\end{array}$ & $\begin{array}{l}\text { Exploratory } \\
\text { laparotomy }+ \\
\text { appendectomy }\end{array}$ & $\begin{array}{l}\text { Transection of the appendix } \\
\text { from its distal half }\end{array}$ & Acute appendicitis \\
\hline Ahmed ${ }^{[17]}$ & $\begin{array}{l}\text { Blunt trauma to the right lower } \\
\text { abdomen from a desk corner }\end{array}$ & $\begin{array}{c}\text { Exploratory } \\
\text { laparotomy }+ \\
\text { appendectomy }\end{array}$ & Perforated appendix & Acute appendicitis \\
\hline Gupta ${ }^{[18]}$ & Bicycle handlebar injury & Open appendectomy & $\begin{array}{l}\text { Appendix was perforated } \\
\text { and fecalith }\end{array}$ & Appendicitis with appendicolith \\
\hline Gupta ${ }^{[18]}$ & Fall & $\begin{array}{c}\text { Exploratory } \\
\text { laparotomy }+ \\
\text { appendectomy }\end{array}$ & $\begin{array}{l}\text { Appendicular lump with a } \\
\text { perforated appendix }\end{array}$ & $\begin{array}{l}\text { Perforated appendix with } \\
\text { inflammation involving all } \\
\text { layers of the appendix }\end{array}$ \\
\hline Seung ${ }^{[9]}$ & Motor vehicle collision & $\begin{array}{l}\text { Exploratory } \\
\text { laparotomy }+ \\
\text { appendectomy }\end{array}$ & $\begin{array}{l}\text { Appendix was transected } \\
\text { completely at its proximal } \\
\text { portion, and the free distal } \\
\text { portion of the transected } \\
\text { appendix was found in the } \\
\text { pelvic cavity (Fig. 4) }\end{array}$ & Not mentioned \\
\hline Jensen ${ }^{[19]}$ & Bicycle handlebar injury & $\begin{array}{c}\text { Diagnostic } \\
\text { laparoscopy }+ \\
\text { appendectomy }\end{array}$ & $\begin{array}{c}\text { Appendix was traumatically } \\
\text { amputated } 1.5 \mathrm{~cm} \text { above the } \\
\text { base }\end{array}$ & Confirmed ruptured appendix \\
\hline Siddiqui ${ }^{[4]}$ & Fall from a ladder & $\begin{array}{c}\text { Diagnostic } \\
\text { laparoscopy }+ \\
\text { appendectomy }\end{array}$ & $\begin{array}{l}\text { Inflamed retrocecal } \\
\text { appendix consistent with } \\
\text { acute appendicitis }\end{array}$ & $\begin{array}{l}\text { Active inflammatory changes } \\
\text { consistent with acute } \\
\text { appendicitis }\end{array}$ \\
\hline Singh ${ }^{[19]}$ & Bicycle handlebar injury & $\begin{array}{c}\text { Exploratory } \\
\text { Laparotomy }+ \\
\text { appendectomy }+ \\
\text { perforation repair }\end{array}$ & $\begin{array}{l}\text { Jejunal perforation with } \\
\text { appendicitis }\end{array}$ & Acute appendicitis \\
\hline AlJaberi ${ }^{[20]}$ & Motor vehicle collision & Lower midline & Free fluid in the abdomen; a & Not mentioned \\
\hline
\end{tabular}




\begin{tabular}{|c|c|c|c|c|}
\hline & & $\begin{array}{l}\text { exploratory } \\
\text { laparotomy }\end{array}$ & $\begin{array}{l}\text { completely transected } \\
\text { appendix }\end{array}$ & \\
\hline Çağlar ${ }^{[21]}$ & Fall from a swing & Not mentioned & $\begin{array}{l}\text { Inflamed and perforated } \\
\text { appendix }\end{array}$ & Acute appendicitis \\
\hline O'Kelly ${ }^{[22]}$ & $\begin{array}{l}\text { Kick to the abdomen during a } \\
\text { soccer game }\end{array}$ & $\begin{array}{l}\text { Lower midline } \\
\text { exploratory } \\
\text { laparotomy }\end{array}$ & $\begin{array}{l}\text { Disintegrated perforated } \\
\text { appendix }\end{array}$ & $\begin{array}{c}\text { Evidence of a dense } \\
\text { inflammatory infiltrate and } \\
\text { necrotic fragments }\end{array}$ \\
\hline
\end{tabular}

RTA: Road Traffic Accident

\section{Discussion}

Traumatic appendicitis and post-traumatic appendicitis are controversial terms. Fowler ${ }^{[3]}$ listed three criteria for using the term traumatic appendicitis: (1) The patient should be previously healthy with no history of pain attacks prior to the trauma; (2) the force of the trauma should be directed to the abdomen; and (3) the effects of the trauma must progress to appendicitis symptoms, such as pain. The time interval between the trauma and presenting symptoms is $1-72$ hours $[6,11-14]$. All the cases

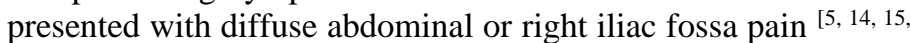
22]

The pathophysiological mechanism is still unclear. Several theories have been formulated; however, a definitive cause has not been found. Hennington proposed that trauma that indirectly causes cecum contusion, mesenteric disruption, and enlarged lymph nodes could lead to the obstruction of appendiceal lumen, and this could lead to bacterial infection [1]. The bacterial infection would lead to the cycle, which eventually could lead to perforation ${ }^{[1]}$. A second theory has suggested that the position of the appendix could be a cause of traumatic appendicitis ${ }^{[15]}$. Post-traumatic appendicitis is unlikely to develop in a retrocecal appendix because of the protection from the cecum against the increased intra-abdominal pressure caused by trauma. However, it is more likely to occur in a pelvic appendix or appendix in the inguinal hernia (Amyand's hernia) ${ }^{[15]}$. A third theory has posited that the sudden increase of intra-abdominal pressure on the appendix could lead to inflammation, edema, and lumen obstruction ${ }^{[20]}$. A fourth theory is that the combination of appendicular fecalith and cecum trauma could cause an appendix lumen obstruction and infection ${ }^{[20]}$.

Appendiceal transections have been reported after seat belt injuries and bicycle handlebar injuries to the abdomen ${ }^{[8,9,19,21]}$. In these cases, a transection of the appendix was identified intraoperatively $[8,9,19,21]$. The causes were crush or deceleration injuries ${ }^{[8,9]}$. In one case, acute appendicitis was reported after a penetrating abdominal stab wound ${ }^{[10]}$. A right paracolic retroperitoneal hematoma was found with cecal and appendiceal wall hematomas intraoperatively. This might have led to compression on the cecum and appendix and the subsequent obstruction of the appendix lumen ${ }^{[10]}$.

Blunt abdominal trauma from handlebar injuries or kicks directly in the abdomen in children should raise the index of suspicion of possible internal organ injury ${ }^{[12]}$. Abdominal ultrasonography could assist in the diagnosis of appendicitis in children ${ }^{[12]}$. In adults for whom traumatic appendicitis might be caused by seat belt trauma, road traffic accidents (including those involving motor vehicles), assaults, or falls from ladders $[11,9,5,14,16,15]$, abdominal ultrasonography and computed tomography of the abdomen are helpful tools in diagnostic confirmation ${ }^{[2]}$.

\section{Conclusion}

Acute appendicitis after abdominal trauma is rare and controversial. Several theories have attempted to explain the relationship between trauma and appendicitis; however, no definitive cause has been found. For abdominal pain presentation after trauma, emergency physicians should consider appendicitis in the differential diagnosis.

\section{Conflicts of interest}

The authors have no conflicts to declare.

\section{Sources of funding}

There was no source of funding.

\section{References}

1. Hennington MH, Ellis J, Tinsley A, Herbert CCB, Proctor J. Acute Appendicitis Following Blunt Abdominal Trauma: incidence or Coincidence? Annals of Surgery. 1990; 214:61-63.

2. Khilji MF, Ullah QZ. Case Report Seat Belt Compression Appendicitis Following Motor Vehicle Collision. Case Reports in Emergency Medicine, 2017, 3-5.

3. Fowler RH. The Rare Incidence of Acute Appendicitis Resulting from External Trauma. Annals of Surgery. 1938; 107(4):529-539.

4. Siddiqui J, Oliphant R, Yeh ZY, Suen M. Appendicitis: A Traumatic Etiology. Journal of Case Reports. 2018; 8(3):176-178.

5. Wani I. Post-Traumatic Retrocaecal Appendicitis. OA Case Reports. 2013; 2(4):31.

6. Ciftci AHAO, Tanyel FC, Büyükpamukçu N. Appendicitis after Blunt Abdominal Trauma: Cause or Coincidence? European Journal of Pediatric Surgery. 1996; 6(6):350-353.

7. Thomas DFM. Injury to the Appendix after Blunt Abdominal Trauma. The British Medical Journal. 1978.

8. Moslemi S, Reza H. Co-Incidence of Acute Appendicitis and Appendiceal Transection after Blunt Abdominal Trauma: A Case Report. 2013; 38(4):343-346.

9. Go SJ, Sul YH, Ye JB, Kim JS. Appendiceal Transection Associated with Seat Belt Restraint. Annals of Surgery Treatment and Research. 2016; 91(2):93-95.

10. Bouassria A, Majdoub KI, Yazough I, Ousadden A, Mazaz K. Traumatic Appendicitis: A Case Report and Literature Review. World Journal of Emergency Surgery. 2013; 8:31.

11. Hagger SSR, Constantinou J. Acute Appendicitis After a Fall from a Ladder: A Traumatic Aetiology. Emergency Medical Journal. 2002; 19:366-367.

12. Ramesh TJG, Who P, Lng K. Appendicitis Following Blunt Abdominal Trauma. Medical Journal of Malaysia. 2002; 57(1):123-124.

13. Karavokyros I, Pikoulis E, Karamanakos P. A Case of Blunt Abdominal Trauma and Posttraumatic Acute Appendicitis. Turkish Journal of Trauma and Emergency Surgery. 2004; 10(1):60-62.

14. Etensel MEB, Yazıcı M, Gürsoy H, Özkısacık S. The Effect of Blunt Abdominal Trauma on Appendix Vermiformis. Emergency Medicine Journal. 2005; 22:874-877.

15. Toumi Z, Chan A, Hadfield MB, Hulton NR. Systematic Review of Blunt Abdominal Trauma as a Cause of Acute Appendicitis. Annals of the Royal College of Surgeons in England. 2010; 92:477-482. 
16. Torres-Grau J, Monkhouse SJW. Trauma Induced Appendicitis ... A Real Entity Torres. Am. Med. J. 2012; 3(2):124-125.

17. Ahmed ST, Ranjan R, Saha SB, Singh B. Traumatic Appendicitis Misdiagnosed as a Case of Haemoperitoneum, 2014, 2013-2015.

18. Gupta R, Mathur V, Bansal J, Bhandari A. Acute Appendicitis Following Blunt Abdominal Trauma in Children: By Chance or A Cause? Formosan Journal of Surgery, 2016, 1-6.

19. Jensen A, Baertschiger R, Hackworth J, Rescorla F. Blunt Abdominal Trauma with Handlebar Injury: A Rare Cause of Traumatic Amputation of the Appendix Associated with Acute Appendicitis. Journal of Pediatric Surgery Case Reports. 2016; 7:13-15.

20. Aditya Pratap Singh RP, Gupta Arun Kumar, Barolia DK. Blunt Trauma Abdomen-Induced Jejunal Perforation with Appendicitis. Medical Journal of Dr. D. Y. Patil Vidyapeeth. 2018; 11:371-373.

21. Aljaberi LM, Eddin A, Salameh K, Almarzooqi RM, Emar MF. Transection of the Appendix and Omentum Following a Seat Belt Injury: Case Report and Literature Review. Annals of Medicine and Surgery. 2018; 34:11-13.

22. Aykut Çağlar HA, Er, Anıl Atacan, Özge Gülcü, Pelin Genç, Sinan Çağlar İlknur, Çelik Tanju. A Child with Acute Appendicitis Secondary to Blunt Abdominal Trauma: A Case Report and Review of the Literature. Journal of Pediatric Emergency and Intensive Care Medicine. 2018; 5:140-143.

23. O'Kelly JRF, Lim KT, Hayes B, Shields W, Ravi N. The Houdini Effect-An Unusual Case of Blunt Abdominal Trauma Resulting in Perforative Appendicitis. Irish Medical Journal. 2019; 105(3):86-87. 